
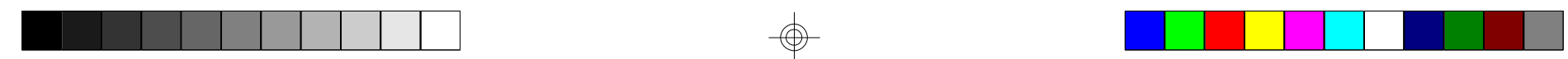

GEOUSP - Espaço e Tempo, São Paulo, No 18, pp. $201-212,2005$

\title{
ASPECTS OF GARDEN CULTURE AND OPEN SPACE DEVELOPMENT IN GERMANY
}

\author{
Gert Groening*
}

\begin{abstract}
:
The lecture consists of six parts. Part 1 includes a few remarks to the reductionist approach of ecology and early attempts of arborization in Germany. Part 2 addresses elements of an open space theory in an urbanizing world of the twentyfirst century. The third part relates to various meanings and ambivalent values attached to open space elements. Part 4 points to garden culture and open space interests as political issues in democratically constituted societies. In part 5 a number of examples are given in favor of garden culture and open space development in Germany. Here I will especially refer to three planning levels of activities in favor of garden culture and open space development. The lecture ends with brief touches on such points as leisure, housification processes, uneven distribution of open spaces, nativism, and genetically engineered plants.
\end{abstract}

\section{I - A few remarks to the reductionist approach of ecology and early attempts of arborization in Germany}

Many publications of the late twentieth and early twentyfirst centuries popularize a biological way of looking at the world. The late twentieth century saw the introduction of what then was called biosphere. Characteristic for such views is that humans and their spiritual, intellectual, and social dimensions are not part of this reasoning which quite often is called "ecological". It seems not surprising then to see representations of a city that claim to be "ecological" and which at the same time almost completely neglect the manifold human relations and achievements in a city. As in late nineteenth century, some ecologists of the late twentieth and early twenty-first centuries view big cities as elements which are destructive to what they consider as nature. ${ }^{1}$ If at all acceptable, then to them big cities seem "tolerable" at best. They seem to have difficulties to see any constructive forces in big cities. Such views are remarkable since there is a world-wide trend to urbanization.

Against such ecologists' views, the people, who are the driving force behind this trend, obviously prefer cities to those "natural, ecologically intact" areas which they have left because they hoped or knew they would make a better living in the cities. The neglect of the social, economic, and political aspects of human development is a cardinal mistake of the so-called ecological point of view. This "ecological" view tries to make believe, that the incredibly complex processes of the civilization of several hundred millions of people on this earth are negligible. As if ecology had nothing to do with civilisation. This I find remarkable.

How important it is to include the social, political, and economic dimensions of 
human civilization must be obvious to all who think of changing a situation from bad to good. This refers to arborization also.

As early as 1821 Gustav VORHERR (17781847), an advocate of the arborization of the territory of villages in Bavaria, had to learn that his proposals were not followed since he had not considered his fellow citizens views upon this subject. ${ }^{2}$

In the course of the nineteenth century many city streets became arborized. For example the city of Mannheim provided various plans for the arborization of her streets. Another meaningful early idea for the arborization was the establishment of national tree nurseries which would hand to all those citizens who were willing to care for, trees at especially favorable conditions. This was an idea which Peter Joseph LENNÉ (1789-1866), ${ }^{3}$ whom many consider the ancestor of landscape architects in Germany, had suggested in the early nineteenth century already and which became implemented with the establishment of a national tree nursery and a school for the training of gardeners in 1823 in Prussia, and a superbly edited journal, the "Transactions of the association for the promotion of horticulture in the royal Prussian states" (Verhandlungen des Vereins zur Beförderung des Gartenbaus in den königlich preussischen Staaten).

Once it is understood that changes can not become effected on an individual basis but need joined forces, need the formation of coalitions, and a lot of political activity, then the need for knowledge about human interests is clear.

\section{II - Towards an open space theory in an} urbanizing world of the twentyfirst century

Each discipline must try to establish a theory if it wants to find a framework for the results from various individual research efforts. This is a far from easy task. It appears that in the landscape architecture of the last decades in Germany the term "ecology" often served to disguise the lack of a theory which would enable to locate whatever "ecological" results. A number of other disciplines, such as medicine, musicology, chemistry, physics, ${ }^{4}$ in literature, and in art history, show more theoretical reasoning than landscape architecture. Nevertheless landscape planning often claims to be the only discipline with an ecological view as opposed to all the others.

With respect to Germany this is bizarre. Until very recently there is a strong interest in what has been called 'land maintenance' (Landespflege) by National Socialist landscape planners. Some in Germany still have difficulties to clearly depart from such positions after the liberation from National Socialism ${ }^{5}$ which happened fairly precisely 60 years ago.

So with respect to that landscape planning in Germany still has not managed to clearly depart from such National Socialist leanings. In 2002 a conference in Berlin about nature protection and National Socialism found nothing wrong with nature protection and National Socialism. ${ }^{6}$ This is remarkable to the extent that all high-ranking representatives of nature protection were actively engaged in National Socialist activities and had supported racist and nationalistic thinking. ${ }^{7}$

The social scientist Norbert ELIAS (1897-1990), who thoroughly studied the process of civilization, developed a meaningful hypothesis. His research revealed that in the course of civilization in European societies the need to check emotions, passions, and impulsivity became more and more significant. ${ }^{8}$ In support of this hypothesis I think it will become more and more meaningful for the development of civilization to check democratically how the different groups of a society appropriate and dominate nature. Within such a procedural framework paths may open up towards a (garden) theory as part of the issues of garden culture and open space development in an urbanizing world of the twentyfirst century. 


\section{III - The various meanings and ambivalent values attached to open space elements}

For me the interest in urban arborization belongs within the idea of garden culture and open space development. Garden culture and open space development are conscious and long-range exchanges with non-human nature. As any other human activities, garden and open space related activities can become questioned how deliberate and how far-reaching they have been conceived.

In this case I take it for granted that those who comply with these standards by themselves may ask others what they think about such established rules. Garden culture and open space development take off from a democratically constituted state. Those who advocate it understand that their interests compete with other legitimate open-space-related interests in a society. Respective activities must become effected in a rational discourse. For the implementation of their goals garden culture and open space development explicitly apply results from social science and art history research. Garden culture and open space development essentially embrace the socially mediated aspects of the history, the design, and the use of gardens, parks, and other open spaces.

This is different from an "ecologically" oriented landscape planning which is based on selectively applied scientific results only, and which claims to act in the interest of a seemingly objective "ecological" interest of "nature". When humans claim to plan in the interest of nature they overlook that this is nothing else but one of many other human interests. The nature which antecedes human history and civilization is the nature "which nowadays exists nowhere any longer", as Karl MARX (1818-1883), the German social philosopher and chief theorist of socialism and communism, has realized in the nineteenth century already. ${ }^{9}$

So even non-human nature, such as soil, water, air, also plants and animals, can only become understood as a product of societal exchange. Notions of "nature" are always shaped by individual perception which is socially and culturally mediated.
In a recent research Uwe SCHNEIDER and myself have shown how the perception of the heath 'landscape' changed within the last century or so. ${ }^{10}$ The heath is a fairly widespread kind of vegetation in Europe. In a fairly complex process its perception shifted from an almost despised area in late nineteenth century Germany into a most appreciated one in the course of the twentieth century.

These changes were far from "natural". Literature, painting, plant geography, photography, landscape architecture, racist ideology, tourism, psychology, and many other aspects were involved. We know of many such changes which for whatever reasons have not been particularly well researched with respect to garden culture and open space development. This includes the shifting preferences for certain types of landscapes as well as those for plants.

With respect to landscapes, the 'Alps', and with respect to plants, the 'tulips', are two more examples for such shifts in perception. It is well established how the Alps turned into a major tourist attraction in the course of the twentieth century, and how crazy people were after tulips, especially in the Netherlands, some centuries ago.

This also holds true for the notion of landscape, an equally woolly and special category. ${ }^{11}$ The wooliness of the category turns even worse when it is used in word combinations such as landscape ecology and landscape architecture, as if to lend ecology and the architecture which it feels related to, a status of eternity and of timelessness. However, the perception of 'landscape' never was and never will be stable.

Landscape ecologists, landscape planners, and others who believe they can make a contribution to improve the open space situation of other people, should, wherever they may work, try to understand the meaning of open space for various groups of the population. For professional standing it may prove helpful to be aware of the meanings oneself has attached to various open spaces and elements of open spaces, such as trees for example, in the course of one's own life. 
As research shows it is wise to be modest with assumptions about the interest, the use, the appreciation of the design, and of the history of open spaces as well as the knowledge about plants, soil, water, air, and many other factors, let alone their interrelatedness.

Qualities and quantities of open space may become appreciated fairly different in various social and cultural situations. However, to be able to discover such variations, to address them from a social scientist, a designer, and a user perspective is a meaningful activity of garden culture. To some extent, and in some countries, one can even refer to empirically researched material.

For a number of years in the mid 1970s many people associated in groups and called themselves 'Buergerinitiative', citizens' initiative, in Germany. These groups quite frequently voiced their interest in higher quantitative and higher qualitative standards of open spaces not only in the cities but in rural areas also.

Over the years out of these citizens' initiatives a "green" movement formed which after a while also took part in those partypolitical processes known as democracy. There, for the first time since the Weimar Republic, the meaning of open spaces was made a matter of public interest again. This formation took place in large cities and in urban agglomerations. In such places the number of votes in democratic elections became large enough to first influence open space politics on local, later, in the early 1980s, also on state and federal levels.

Not surprisingly some of the interests voiced, went beyond what others felt they could bear. More often than not this related to rural areas with an agricultural background. Here the eco-urbanites were sometimes met with considerable resistance if not hostility.

Although the so-called environmental awareness gained considerable popularity in the 1980s, it seems characteristic for many ecourbanites that they share a fairly ambivalent relation to non-human nature as it is still present in some of the more remote areas in their countries. They tend to overlook that even agriculture, which many consider a kind of preindustrial activity, has become completely industrialized. So increasing numbers of people have to realize that the long-standing tendency towards urbanization and industrialization, which they propel by their various activities, also encompasses agriculture. Here they seem to become aware of a discrepancy.

The open-space-nature which they have been shown at schools and in art museums as 'landscapes' of the eighteenth and nineteenth centuries in paintings and in literature differs strongly from the industrialized agricultural areas next to the cities in which these urbanites lead relatively comfortable lives.

Some voice this experience of discrepancy in public. This is one side of the relationship to non-human nature. From here one could approach an idea to create a paradise. Nevertheless Christians know that they have been driven from paradise a long time ago. Some may reflect their own distance from what they consider nature and may realize that this nature will for ever remain beyond their reach. The best they can do is dream it up, write about it, compose it, put it on stage, paint it, or worship it. Some may have realized that there is no way to paradise, and some may even reject the idea to ever be in a paradise. Most of us are not interested to live in real nature. From our history of civilization and urbanization we have learned that we are much better off if we perceive this non-human nature selectively, and only if it is prepared for our ways of perception and experience.

So "close to nature" is a fairly inept category if one wants to locate garden culture and open space development within the framework of social and political activities. What everyone can do is to try to locate herself or himself in a way which allows to see and reflect the changes in the perception of "nature" which accompany her or his life with respect to the various attempts to get a sense of the kind of nature appropriation considered necessary, both for spiritual and material enjoyment. 
When I try to imagine what the twentyfirst century may have in store for garden culture, then it may not be a long way to go to design your own flowers, shrubs, and trees. What consequences this will have I do not know. However, I think it would be wise for those interested in garden culture and open space development to start thinking about such issues. As I have just indicated there never was and there never will be an unchanging position. Thus trying to make sense I understand garden culture and open space development as part of an approach to democracy.

\section{IV - Garden culture and open space interests as political issues in democratically constituted societies}

Although I have been explicit about the relative social and political meaning of garden culture and open space development there is a host of related tasks for the urbanizing societies of the twentyfirst century. Garden culture and open space development can participate in the ongoing process of civilization and urbanization. However, it is necessary to soberly assess the role this field can play on the various stages.

Two points seem of outstanding significance. First of all I deem it more important to talk to people, find out about their interests, and to offer assistance, than to commission another ecological analysis or another biodiversity study. Second, it is more important to apply scientifically proven results and artistic creativity, than to conjure mystic ideas about gardens and landscapes.

As the 'Kleingarten' movement in Germany proves since more than one hundred years, gardening in an association is a powerful political and social facet of urban garden culture. ${ }^{12}$ At a recent conference in Berlin, Germany, ${ }^{13}$ representatives from as far away as Japan, Bangladesh, Russia, the United States of America, and a number of other places, have shown that there are many countries around the world where similar interests as those in the 'Kleingarten'-movement in Germany are voiced.
In Japan e.g., where many Europeans, and may be many of you Brazilians also, tend to think there is no space at all for gardening, quite a number of 'Kleingarten' sites have been established in recent years. Not the least the growing interest in these matters in Japan's largely urbanized society is reflected in a new journal, The Journal of the Japanese Society of People-Plant Relationships, which has been launched in 2001. ${ }^{14}$ And more than that, as one of the few countries around the world, the Japanese democracy has produced two laws which rule allotment gardening in this nation.

Last year when I participated in the VII Congress on Urban Arborization in Belem, Pará, I learned of a study which addressed the garden needs of the urban poor in Belém. ${ }^{15}$ However, in many instances, the overall social, political, and economical dimensions are not (yet) understood appropriately.

In Japan, and in many other places around the world some trees in the cities are visibly worshipped.

To enjoy garden culture, which includes trees and other open space related elements in an urban environment needs the articulation of such interests in the various political bodies of the communities, the counties, the states, and the nation. Such interests also need to be integrated into party-political programs in order to become effective in democratically constituted societies. ${ }^{16}$

Ideas about garden culture and open space development should not become presented entirely independent from other issues or even as a kind of martyr program, at least not in the public sector. For example those who are actively providing open space for garden culture, for childrens' playgrounds, for trees, etc., can and should join talks about crime prevention in urban environments. If they do not, the social and cultural values they associate with various kinds of open space elements will not be known to politicians and other decision makers.

Instead of "ecological" ethics social practice is asked for in garden culture and open 
space planning. ${ }^{17}$ Next to talking, to provide both written and designed plans on various levels of political decision making is an important tool.

\section{V - Examples of planning activities in favor of garden culture and open space development in Germany}

The planning levels on which activities in favor of garden culture and open space development can take place in Germany I have compiled in a table which I have called "Scheme of Open Space Plans".

Without to explain this in detail I want to point to three levels of planning which seem appropriate in democratically constituted societies to tackle urban open space planning issues. These levels themselves are not separated so sharply from each other as the scheme might suggest. Level one refers to the open space system in a region or a city. Another level is the open space structure in a city or a smaller political unit. Level three relates to the open space infrastructure, that are the elements which shape a given open space.

In one way these plans relate to the invention of land use planning in the late nineteenth century in Germany. ${ }^{18}$ In another way they are a far cry from the late nineteenth century plans since such plans have become more and more refined.

If one wants to arborize urban areas or if one wants to create parks and other recreation areas, then such ideas must become incorporated into the various planning levels. This includes the neighborhoods, the communities, the counties, the states, and the nation as a whole. And as world-wide integration increases, it encompasses also the corresponding political programs on Southamerican, European, and ultimately world levels. 19

Those who consciously follow the goal to establish open space elements in order to enhance pleasure and environmental enjoyment, who successfully want to secure open spaces for recreation and nature protection, need to present their views in opinions, plans, and suggestions to the representatives of federal and state diets, to the members of community councils and various other boards involved in decision making, and to their commissions.

So, for example, since 2001 the city of Bremen implemented her open space policy along the lines of what it has called the 'Green Net Bremen'. For all of the 19 boroughs the existing green net which encompasses green areas, parks, allotment gardens, cemeteries, track- and field areas, urban squares, and green connections is registered and evaluated on a scale of 1:5000. Deficits are analysed, in order to develop planning proposals for the open space development of the boroughs. Other, than with many 'conventional' plans the open space users deliberately participate in these processes. In many rounds of experts on site the heads of the local authorities, the borough politicians, landscape architects and city plannners, heads of the local garden departments, and representatives from citizens' initiatives meet in order to accompany the project". ${ }^{20}$

For Munich the architect LAUX developed an 'Open System' in the early twentyfirst century which in an exemplary way builds upon the idea of an open space system. The net of open spaces in LAUX' 'Open System' does not restrict itself to green structures only. However, it includes all categories of open spaces. Next to regionally meaningful open space structures which some may call 'landscape', and green connections of a higher order, significant infrastructure supplements the system. In what is called the Munich North, Münchner Norden, this encompasses track and field areas, agriculture, gardens and green zones such as the Isar flood plains and the English Garden, the trails for the S-Bahn, the Isar canal, and many major arteries. In this way open space planning turns into an instrument which allows to check the development of various kinds of open spaces. It works as part of a net structure and a stable system of order which can become enlarged. Building is subordinated to this open system". ${ }^{21}$ 
A comparable open space development plan, and one which could well be worth serious consideration for São Paulo is what has been named the "Master Plan Emscher Landscape Park", Masterplan Emscher Landschaftspark, 2010. This plan is more like a framework for future action which serves as a basis for local decisions within a regional context. The goal of this open space plan is "shrewd management", "intelligente Steuerung", of the development in a fairly large area which, if there is a chance at all to compare any region in Germany, may be compared to the area of São Paulo. This plan was commissioned in summer 2002 and at present is on the table for the seventeen cities, the two counties (Landkreise), the three governmental districts (Regierungsbezirken), the Emscher associates and Lippe Association (Emschergenossenschaft / Lippeverband), the Rhuhr area association of communities (Kommunalverband Ruhrgebiet), and the state of Northrhine-Westfalia (Land NordrheinWestfalen) to pass as a resolution. It follows a longstanding tradition of open space planning in this region ${ }^{22}$ which has been established by the "Ruhr area settlement association", Ruhrsiedlungsverband, during the first period of democracy in Germany in the 1920s. The goals of this open space plan are:

- to reach consensus about centers of development within the Emscher region,

- to agree upon the dimensions of the new Emscher valley as the leading project,

- the integration of the restruction of the river and the construction of the park,

- active integration of agriculture into the construction of the park and in ist maintenance,

- continuity and development of successful centers such as culture of industry and nature, new parks, as well as landmarks and landmark art,

- the appropriation of the urban landscape and the development of new ways of perception via art

- the further development of the infrastructure of the park and the information about the park,

- the care and the maintenance of the park,

- the financial basis of the park,

- an obligatory agreement for the development of the park in the years to come between all participating institutions. ${ }^{23}$

From these examples it is obvious that to foster and to heed such ideas in private chambers or away from democratic institutions leads nowhere. Time and again there is the need of early and comprehensive information of those who are supposed to profit from such planning. When for example, the new nature protection law of the Federal Republic of Germany demands to create "a biotope-net-system for ten percent of the territory at least"24 and the owners of the land know nothing about this, then conflict is programmed. 25

VI - A very brief look at other meaningful issues in garden culture and open space development, such as leisure, housification processes, uneven distribution of open spaces, nativism, and genetically engineered plants

Many more points seem important for the future of garden culture and open space development as part of urban civilisation. In concluding I will only very briefly address some of these.

Although exchanges about the increasing amounts of leisure were quite popular in the 1960s and 1970s in Germany and elsewhere in Europe, the assumption that leisure will increase seems questionable in many instances.

As a concomitant to this debate, the use of open space needs to be reflected also. Will it increase or will it decrease or will it be a more or less stable variable?

At least with respect to the interest to have a place near the water, and enjoy some music not much seems to have changed within the last century or so in Germany, and I assume in Brasil also. Also it appears as if during the twentieth century open space related interests have increased rather than decreased. 
However, one can also assume that a number of once self evident open space activities tend to become located in buildings. This process is known as the housification of open space activities. This relates for example to activities such as soccer, climbing, swimming, tennis. It can relate to trees also. The process of housification also relates to the crystal palaces in which we care for some of the plants and animals which can not stand the local climate. And last but not least this process also affects one of the major activities of humans at the beginning of the twentyfirst century, shopping in shopping malls where you can find arborization also.

When the nuclear power plant in Chernobyl, Russia, blew up in spring 1986 not only the idea to use open space for the sake of enjoyment and health but also the idea to grow food outdoors was severely shaken in many European countries, including Germany. When in spring 2000 the major nuclear powers of the world agreed to stop the production of nuclear weapons this was a first step to a needed ban of this mad technology. It will still be a long way before the final agreement will be reached. Nevertheless I think it was mainly due to the interest of many people, voiced through the environmental movement, to enjoy recreation in, and fruit and vegetables from, uncontaminated outdoors, which enforced this agreement.

I find it strange to read in contemporary open space plans more and more information about the frequency of butterflies and other insects as well as certain plant species in a given location than about the quality and quantity of various open spaces which people can enjoy in a city. Do we talk so much about insects and plants because we have given up hope with humans? Other open space categories such as open spaces in residential areas seem to be completely neglected. At the same time the unequal distribution of open space is easily visible in the cities. This is not a law of nature. It is man-made.

To address such unequal distribution of open space is a meaningful task of open space planning. ${ }^{26}$ Shall the situation become worse, shall it become stabilized, or shall it become improved? What then does that mean for the use and the design of the open spaces? To me, answers to these questions seem more relevant than the ubiquitous hints towards endangered plant and animal species.

If what I have called the ambivalent relationship of humans to non-human nature, is valid, then it should be clear that the vast majority of us have no interest to return to a pre-industrial, nineteenth-or-even-eighteenthcentury-agricultural way of existence. Then garden culture and open space planning should have a closer look at such mediated nature appropriation and its impact. Also the goals which garden culture and open space planning feel obliged to and how they relate to other goals in a society should become a matter of public debate.

Should the amount of open space in a city become reduced to the lowest quality and smallest quantity? Should all of a city become a nature protection area? Should all available open spaces become developed for industrial and commercial activities? Who should decide about such issues?

Plans, designs for, and histories of parks and gardens and other open spaces should attempt to bring into public debate those values which encourage to stay outdoors. This is a vast field which has only marginally been ploughed.

As long as millions are spent for the mapping of plant and animal species only, and not for urgently needed research into the everchanging needs and interests of people, the basis of landscape plans lacks the most important part.

Strange as it may appear, quite frequently the open space related interests fight each other. One example is the fight for more funds and publicity against other interests. Charles R. JORDAN, the dynamic director of Parks and Recreation in Portland, Oregon, is not afraid to talk about a "war" which the American National Parks wage against the parks in the 

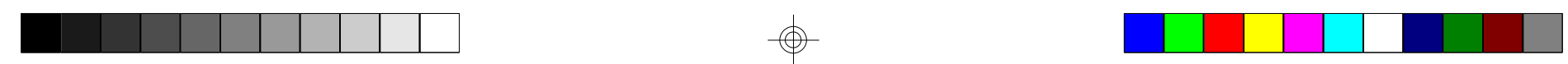

cities and the big agglomerations. JORDAN found that in the United States of America ninety percent of the state money became invested into the national parks which only ten percent of the population visit. Whereas only ten percent of these funds are supplied for state parks and urban parks which are frequented by ninety percent of the population. ${ }^{27}$

Another example is the fight between those who believe the use of so-called "native" plant species must become enforced against those who use so-called "non-native" plants. This fight is not new. ${ }^{28}$ It has shown up several times during the last one hundred years or so in Germany. Especially within the last two decades the stupidity of the case seems as attractive as ever. ${ }^{29}$

On a larger scale such absurd distinction between "native" and "non-native" even made its way into international literature. Siegfried LENZ, a well known German writer, addressed this issue of nativism and the consequences of such a "national" ecology in his novel 'The Training Ground'30 such. During the time of the old Federal Republic of Germany, the Schleswigholsteinian tree nursery owner Zeller who had fled from East Prussia after World War Two, burned 100.000 young oak trees in front of the town hall of the community he lived in, out of disrespect for a ministerial order. He had raised the trees from a mixture of German and Romanian seed. The reason for his behavior is explained such:"A directive has come from the ministry. They'd worked out some new regulations, back there in the ministry, and in order to make them stick, had also dug out some older regulations ... they were the rottenest regulations imaginable: they laid down that all trees must come from German seed, otherwise they were not to be sold. A pedigree, Bruno just think of that: these experts are demanding a pedigree for each single plant, that's what they've worked out back there in their chambers; they want only German seed sown in German soil. All we need now is for them to stipulate German cowshit as manure".. ${ }^{31}$ The main character in LENZ' novel concluded: "Never trust anyone who preaches genuineness and purity ... The apostles of purity bring us nothing but desaster". 32

The more recent invention of genetically engineered plants and the increasingly industrialized production of plants may provoke similar reactions. In many instances, I think, it would be wiser for those who still share an interest in plants to join forces rather than to fight in such side-shows of nativism.

Planning and designing open spaces is nothing else but a kind of interest representation and thus needs to be part of a political process in a democracy. On the other hand ecologists, planners, and designers should not believe they are politicians simply because they have understood that they are part of political processes.

Especially as a conscious participant in the political processes one should be clear about their complexity which sometimes may make it difficult not to loose track of the goal. However, this should not detract from asking questions and seeking for answers which allow to reach the stated goals of garden culture and open space development. That is basically different from waiting for the questions from politicians, then answer them, and then name the instruments by which to reach best the goals of the politicians.

Whenever activities of garden culture and open space development take place, they have to take into account the social situation and the economic and spatial conditions if they want to succeed. Such goals and claims have to be presented and discussed in the context of the ruling ideas about a social state, equal opportunities for all, social justice, constitutionally guaranteed social rights for all, free selection of profession, right for education, free education, free commercial activity and so on. Social, economic, political, and spatial conditions change and are can be changed. Those interested in garden culture and open space development should make suggestions. 


\section{Notas}

${ }^{1}$ See for example the representation of an ecosystem of a city in SUKOPP, Herbert 1973: Die Grossstadt als Gegenstand oekologischer Forschung, TUB, Zeitschrift der Technischen Universitaet Berlin, 5, 710-717.

2 For more about Vorherr's activities see GROENING, Gert 1992: The idea of land embellishment. As exemplified in the Monatsblatt für Verbesserung des Landbauwesens und für zweckmäßige Verschönerung des baierischen Landes (Monthly for improvement of rural architecture and appropriate embellishment of the state of Bavaria), from 1821 to 1829 , Journal of Garden History, 12, 3, 164-182.

${ }^{3}$ See GROENING, Gert 1989: Peter Joseph Lenné und der "Verein zur Beförderung des Gartenbaues in den Königlich Preußischen Staaten", Buttlar, Florian von, im Auftrag der Senatsverwaltung für Stadtentwicklung und Umweltschutz (ed.), Peter Joseph Lenné, Volkspark und Arkadien, 82-90, Berlin.

4 See e.g. MUTSCHLER, Hans-Dieter 1993: Zwei Kulturen sind besser als keine, Wider die physikalistischen Ganzheitslehren, Merkur, 47, 11, 998-1003.

5 See GROENING, Gert and Joachim WOLSCHKEBULMAHN 2003: Zum Verhältnis von Landschaftsplanung und Nationalsozialismus, Siftung Naturschutzgeschichte (ed.), Naturschutz hat Geschichte, Veröffentlichungen der Stiftung Naturschutzgeschichte, volume 4, 163-191, Essen; see GROENING, Gert 1999: Gartenkultur in Klein- und Hausgärten im historischen Wandel, Bundesverband der Diplomingenieure Gartenbau und Landespflege e.V. (Hg.), Beziehung, Mensch und Pflanze im Wandel der Gesellschaft - Garten, Park, Landschaft, BDGL-Schriftenreihe, 7-24, Bonn; see also GROENING, Gert 1998: Die Suche nach der 'Landschaftsmitte', Kursbuch, 131, 55-69, Berlin; see also GROENING, Gert 1997: Ideological Aspects of Nature Garden Concepts in Late Twentieth Century Germany, WOLSCHKE-BULMAHN, Joachim (ed.), Nature and Ideology, Natural Garden Design in the
Twentieth Century, Dumbarton Oaks Colloquium on the History of Landscape Architecture, XVIII, 220-248, Washington, D.C.; see also GROENING, Gert 1996: Der Ueberfall auf Polen und seine Auswirkungen auf daas Konzept der deutschen Landespflege, GROENING, Gert (ed.), Planung in Polen im Nationalsozialismus, 91105, Berlin.

6 See the paper by the organizer of the conference, RADKAU, Joachim 2003: Naturschutz und Nationalsozialismus - wo ist das Problem?, handout for participants of the conference 'Naturschutz und Nationalsozialismus, Erblast im demokratischen Rechtsstaat?', Berlin 3- 5 July 2002, 12 pp. Radkau wrote "that the Nazis for the most part were more or less normal humans" (p.2). Given the systematic extermination of millions of people, which the Nazis considered subhuman, this statement is a shame.

7 See GROENING, Gert 2002: Naturschutz und Nationalsozialismus, Lorenz, Klaus-Peter (ed.), Politische Landschaft - die andere Sicht auf die natürliche Ordnung, 159-187, Duisburg.

8 See ELIAS, Norbert 1976: Ueber den Prozess der Zivilisation, two volumes, Frankfurt am Main.

9 MARX, Karl and Friedrich ENGELS 1959: Werke, volume 3, Berlin; see also GROH, Ruth and Dieter GROH 1993: Natur als Massstab - eine Kopfgeburt, Merkur, 47, 11, 965-979.

10 See GROENING, Gert and Uwe SCHNEIDER 1999: Die Heide in Park und Garten. Zur Geschichte und Bedeutung des Heidemotivs in der Gartenkultur, Gruene Reihe - Quellen und Forschungen zur Gartenkunst, volume 19, Worms. See also GROENING, Gert and Uwe SCHNEIDER (eds.) 2001: Gartenkultur und nationale Identitaet, Gruene Reihe - Quellen und Forschungen zur Gartenkunst, volume 22, Worms.

11 See GROENING, Gert 2003: Über den Landschaftsbegriff, Arbeitsgruppe Mensch Umwelt - Technik TU Berlin (Hg.), "Was ist der Mensch?", Schriftenreihe Technik und Gesellschaft, volume 5, 60-76, Aachen. 

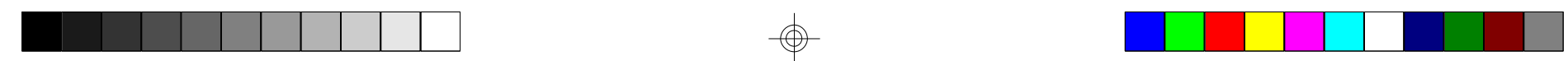

12 See GROENING, Gert 2000: Aspects of Allotment Gardening Politics in Berlin, Germany, between 1985 and 1995, Acta Horticulturae, volume 523, 167-179; see also GROENING, Gert 1996: Aspects of Community Gardening in Germany, City Farmer, Canada's Office of Urban Agriculture, City Farmer's Urban Agriculture Notes, Internet Publication, Vancouver, British Columbia; see also BERTRAM, Christian and Gert GROENING 1996: Leipziger Schrebervereine und ihre gesellschaftspolitische Orientierung zwischen 1864 und 1919, Frankfurt am Main; see also GROENING, Gert and Joachim WOLSCHKEBULMAHN 1995: Von Ackermann bis Ziegelhuette, Ein Jahrhundert Kleingartenkultur in Frankfurt am Main, Studien zur Frankfurter Geschichte, volume 36, Frankfurt am Main; see also GROENING, Gert 1974: Tendenzen im Kleingartenwesen dargestellt am Beispiel einer Grossstadt, Beiheft 10, Landschaft + Stadt, Stuttgart.

${ }^{13}$ See MEYER-RENSCHHAUSEN, Elisabeth, MUELLER, Renate and Petra BECKER (eds.) 2002: Die Gaerten der Frauen, Zur sozialen Bedeutung von Kleinstlandwirtschaft in Stadt und Land weltweit, Frauen Gesellschaft Kritik, volume 35, Herbolzheim.

14 See Journal of the Japanese Society of PeoplePlant Relationships, 1, 2001, 1.

15 See FRÈRE, Nathalie, LUDOVINO, Rui Manuel Rosário and Paulo Fernando da SILVA MARTINS 1998(?): Agricultura urbana em Belém - Para, Universidade Federal do Pará, Brasil.

16 See MILCHERT, Juergen 1984: Tendenzen der staedtischen Freiraumentwicklung in Politik und Verwaltung, Arbeiten zur sozialwissenschaftlich orientierten Freiraumplanung, volume 5, Muenchen.

17 See GROENING, Gert and Joachim WOLSCHKEBULMAHN 1986: Soziale Praxis statt oekologischer Ethik, Zum Gesellschafts- und Naturverständnis in der Jugendbewegung unter besonderer Beruecksichtigung der Arbeiterjugendbewegung, Archiv der deutschen Jugendbewegung, Jahrbuch, 15, 1984/1985, 201-252, Burg Ludwigstein.

18 See LOGAN, Thomas Harvey 1972: The Invention of Zoning in the Emerging Planning Profession of Late-nineteenth-century Germany, Ph.D. dissertation, University of North Carolina at Chapel Hill.
19 See e.g. VERDONCK, O., MATHÉ, A., RELF, P.D., MATSUO, E., GROENING, G., and J. RAMMELOO (eds.) 2000: New and Specialized Crops and Products, Botanic Gardens, and HumanHorticulture Relationship, part 13, Proceedings of the XXV International Horticultural Congress, Acta Horticulturae, 523, Leuven, Belgium.

20 See KNODE, Thomas 2002: Grünes Netz Bremen, Stadt und Grün, 51, 5, 16-23, here p.20.

21 LAUX, Gunther 2002: Transformation: Open System, Garten + Landschaft, 112, 9, 23-25.

22 See GRÖNING, Gert 1998: Die Suche nach der 'Landschaftsmitte', Kursbuch, 131, 55-69, Berlin; see also WOLSCHKE, Joachim und Gert GRÖNING 1984: Regionalistische Freiraumgestaltung als Ausdruck autoritären Gesellschaftsverständnisses?, kritische berichte, $12,1,5-47$.

23 See SCHEUVENS, Rudolf and Jens CÜPPERS 2004: Masterplan Emscher Landschaftspark, Steuerungsintrument Masterplan, Garten und Landschaft, 114, 7, 9-11. See also the other contributions in this issue of 'Garten und Landschaft' which elaborate further the concept of this open space plan by Aufmkolk and Moczala, Kasper and Terfrüchte, Rohler and Fritz, Lohrberg, Lorenz, and Törkel.

${ }^{24}$ See Bundesnaturschutzgesetz 2001, paragraph 3new.

${ }^{25}$ See among others, uj. [Ulrich Jasper] 2000: Neues Naturschutzgesetz, neue Schranken, Unabhängige Bauernstimme, Oktober, Nr. 227, 12-13.

26 See GROENING, Gert 2000: Zur Geschichte schichtspezifischer Freiraumversorgung, Harth, Annette, Scheller, Gitta und Wulf Tessin (ed.), Stadt und soziale Ungleichheit, 102-119, Opladen.

27 See GROENING, Gert 1999: Aspekte der Freiraumplanung im amerikanischen Nordwesten, Stadt und Gruen, 48, 10, 674-679, here p. 677.

28 See GROENING, Gert and Joachim WOLSCHKEBULMAHN 2004: The Native Plant Enthusiasm: Ecological panacea or xenophobia? Arnoldia, 62, 4, 20-28; see also GROENING, Gert and Joachim WOLSCHKE-BULMAHN 2003: The Native Plant Enthusiasm: ecological panacea or xenophobia?, Landscape Research, 28, 1, 75-88. See also THEODOROPOULOS, David I. 2003: Invasion Biology, Critique of a Pseudoscience, Blythe, California. 
29 See GROENING, Gert and Joachim WOLSCHKEBULMAHN 1992: Some Notes on the Mania for Native Plants in Germany, Landscape Journal, 11, 2, 116-126; see also GROENING, Gert and Joachim WOLSCHKE-BULMAHN 1987: Die Liebe zur Landschaft, Teil III, Der Drang nach Osten, Zur Entwicklung der Landespflege im Nationalsozialismus und während des Zweiten Weltkrieges in den "eingegliederten Ostgebieten", Arbeiten zur sozialwissenschaftlich orientierten Freiraumplanung, volume 9, Muenchen, especially chapter "5.3 Fremdlaendische Pflanzen in der ausserstaedtischen Landschaft und Bodenstaendigkeit als Planungsideal". The following may serve as a recent example for this. In 1993 a number of trees were to be cut down in
Berlin for the enlargement of a hospital. The respective authority found that no trees at all must become felled. However, after close inspection it was found that there grew an American oak and a German oak. Once this was detected the German authority gave permission to fell the American oak. The American oak was not German and thus considered less valuable.

30 "Der Exerzierplatz" published in Hamburg, Germany, in 1985; translated into English in 1991 as "The Training Ground", New York, NY.

31 LENZ, Siegfried 1991: The Training Ground, New York, NY, p.382.

32 LENZ 1991, p. 392.

Trabaho enviado em fevereiro de 2005

Trabalho aceito em setembro de 2005 
